\title{
Preoperative ketorolac increases bleeding after tonsillectomy in children
}

William M. Splinter MD FRCPC, Elliot J. Rhine MBChB FRCPC, David W. Roberts MD FRCPC, Craig W. Reid MD FRCPC, Helen B. MacNeill MD FRCPC
Purpose: To compare the incidence of vomiting following codeine or ketorolac for tonsillectomy in children.

Methods: We had planned to enrol 240 patients, aged 2-12 yr undergoing elective tonsillectomy into a randomized, singleblind study in University Children's Hospital. The study was terminated, after 64 patients because interim analysis of the data by a blinded non-study scientist concluded that the patients were at undue risk of excessive perioperative bleeding. After induction of anaesthesia by inhalation with $\mathrm{N}_{2} \mathrm{O} /$ halothane or with propofol $2.5-3.5 \mathrm{mg} \cdot \mathrm{kg}^{-1} \mathrm{iv}$, the children were administered $150 \mu \mathrm{g} \cdot \mathrm{kg}^{-1}$ ondansetron and 50 $\mu \mathrm{g} \cdot \mathrm{kg}^{-1}$ midazolam. Maintenance of anaesthesia was with $\mathrm{N}_{2} \mathrm{O}$ and halothane in $\mathrm{O}_{2}$. Subjects were administered either $1.5 \mathrm{mg} \cdot \mathrm{kg}^{-1}$ codeine im or $1 \mathrm{mg} \cdot \mathrm{kg}^{-1}$ ketorolac iv before the commencement of surgery. Intraoperative blood loss was measured with a Baxter Medi-Vac ${ }^{\circledR}$ Universal Critical Measurement Unit. Postoperative management of vomiting and pain was standardized. Vomiting was recorded for $24 \mathrm{hr}$ after anaesthesia. Data were compared with ANOVA, ChiSquare analysis and Fisher Exact Test.

Results: Thirty-five subjects received ketorolac. Demographic data were similar. The incidence of vomiting during the postoperative period was $31 \%$ in the codeine-group and $40 \%$ in the ketorolac-group. Intraoperative blood losses was $1.3 \pm 0.8$

\section{Key words}

ANAESTHESIA: paediatric, outpatient;

ANALGESICS: ketorolac, postoperative bleeding;

COMPLICATIONS: bleeding;

SURGERY: ENT, tonsillectomy.

From the Department of Anaesthesia, Children's Hospital of Eastern Ontario, University of Ottawa, Ottawa, Ontario, Canada, KIH $8 \mathrm{LI}$.

Address correspondence to: Dr. William Splinter,

Department of Anaesthesia, Children's Hospital of Eastern

Ontario, 401 Smyth Rd., Ottawa, Ontario, Canada, K1H 8L1.

Phone: 613-737-3643. Fax:61-738-4815.

Accepted for publication 7 th December, 1995. $\mathrm{ml} \cdot \mathrm{kg}^{-1}$ after codeine and $2.2 \pm 1.9 \mathrm{ml} \cdot \mathrm{kg}^{-1}$ after ketorolac (mean $\pm S D) P<0.05$. Five ketorolac-treated patients had bleeding which led to unscheduled admission to hospital, $P<$ 0.05, Exact Test.

Conclusion: Preoperative ketorolac increases perioperative bleeding among children undergoing tonsillectomy without beneficial effects.

Objectif: Comparer l'incidence des vomissements après l'analgésie au kétorolac et à la codéine chez les amygdalec. tomisés.

Méthodes: Les auteurs prévoyaient inclure 240 patients âgés de 2 à 12 ans programmés pour une amygdalectomie réglée dans cette étude aléatoire en simple aveugle. L'étude a été terminée après 64 patients après qu'une analyse intérimaire des données par un scientifique sans implication dans l'étude eût montré que les patients étaient soumis à un risque excessif de saignement postopératoire. Après l'induction de l'anesthésie à l'halothane $/ \mathrm{N}_{2} \mathrm{O}$ et au propofol $2,5-3,5 \mathrm{mg} \cdot \mathrm{kg}^{-1}$ $i v$, les enfants ont reçu $150 \mu \mathrm{g} \cdot \mathrm{kg}^{-1}$ d'ondensetron et 50 $\mu \mathrm{g} \cdot \mathrm{kg}^{-1}$ de midazolam. L'anesthésie a été entretenue avec du $\mathrm{N}_{2} \mathrm{O}$ et de l'halothane en $\mathrm{O}_{2}$. Les sujets ont ensuite reçu soit de la codéine $1,5 \mathrm{mg} \cdot \mathrm{kg}^{-1}$ im soit du kétorolac $1 \mathrm{mg} \cdot \mathrm{kg}^{-1}$ iv avant la chirurgie. La perte sanguine peropératoire a été déterminée avec une dispositif de mesure Baxter Medi-Vac ${ }^{\circledR}$. Le traitement postopératoire des vomissements et de la douleur a été uniforme. Les vomissements ont été enregistrés pendant 24 heures après l'anesthésie. Les données ont été comparées par ANOVA, l'analyse du Chi ${ }^{2}$ et le test d'exactitude de Fisher.

Résultats: Trente-cinq enfants ont reçu du kétorolac. Les données démographiques étaient identiques. L'incidence des vo. missements en postopératoire a été de $31 \%$ dans le groupe codéine et de $40 \%$ dans le groupe kétorolac. Les pertes sanguines peropératoires ont été de $1,3 \pm 0,8 \mathrm{ml} \cdot \mathrm{kg}^{-1}$ après la codéine et de 2,2 $\pm 1,9 \mathrm{ml} \cdot \mathrm{kg}^{-t}$ après le kétorolac (moyenne \pm $E T), P<0,05$. Cinq patients traités au kétorolac ont eu des saignements qui ont nécessité une réadmission à l'hôpital, $P<$ 0,05 .

Conclusion: Le kétorolac adininistré en préopératoire augmente sans effets bénéfiques les saignements périopératoires chez les enfants amygdalectomisés. 
Vomiting by children after tonsillectomy is a common problem of multifactorial aetiology. One contributing factor is the choice of intraoperative analgesic. This study was designed to compare the effect on postoperative vomiting of two different analgesics, codeine and ketorolac, administered during anaesthesia for tonsillectomy in children.

Codeine is a popular opioid used in paediatric day care surgery and has a record of safety and efficacy. Unfortunately, it is not effective for all patients and it is associated with a 15-20\% incidence of vomiting, which is an important and expensive problem. ${ }^{1}$

Alternatives to opioids have been developed in an attempt to reduce side effects and improve efficacy. ${ }^{2}$ Non-opioids include acetaminophen and non-steroidal anti-inflammatory drugs (NSAIDs). When compared to acetaminophen, NSAIDs are more effective analgesics, but have a greater incidence and severity of adverse effects.

Ketorolac is a recently-released, efficacious NSAID that can be administered parenterally and orally. Several studies in adults and children have demonstrated the opioid-sparing effect of ketorolac, ${ }^{3,4}$ that may reduce the incidence of adverse effects such as respiratory depression, nausea and vomiting. ${ }^{3}$ Features that may limit its usefulness include gastrointestinal irritation, and the potential for impaired platelet function. ${ }^{5}$ At the time that the current study was initiated, there were no adult or paediatric studies reporting severe post-operative bleeding after the perioperative use of ketorolac, ${ }^{6-11}$ although Bean et al. had reported that 180 min after ketorolac the bleeding time was increased. ${ }^{12}$

We studied the effect of two different analgesic regimens on pain relief after tonsillectomy and hypothesized that ketorolac usage would be associated with a lower incidence of vomiting, than our standard analgesic, codeine.

\section{Methods}

With parental consent and the approval of the local Ethics Committee, 64 healthy (ASA class I-II) patients of aged 2-12 yr undergoing elective tonsillectomy or adenotonsillectomy were studied. Patients were excluded if they were allergic to any of the study drugs, a history of bleeding diathesis or if they had a history of chronic, therapeutic administration of analgesics.

In the event that preoperative sedation was required, the child was given $0.5 \mathrm{mg} \cdot \mathrm{kg}^{-1}$ midazolam po or $s l$ 20-30 min before anaesthesia. Standard patient monitors included ECG, non-invasive blood pressure, temperature probe (axillary), pulse oximeter, capnograph and an end-tidal inhalation agent monitor. Anaesthesia was induced by inhalation with $\mathrm{N}_{2} \mathrm{O} / \mathrm{O}_{2}$ /halothane or with propofol $2.5-3.5 \mathrm{mg} \cdot \mathrm{kg}^{-1}$ iv. Mivacurium, 0.25 $\mathrm{mg} \cdot \mathrm{kg}^{-1}$, was administered if a muscle relaxant was indicated and then an endotracheal tube was inserted.

After induction of anaesthesia, the subjects were given $150 \mu \mathrm{g} \cdot \mathrm{kg}^{-1}$ ondansetron iv (maximum dose $8 \mathrm{mg}$ ) and $50 \mu \mathrm{g} \cdot \mathrm{kg}^{-1}$ midazolam iv (maximum dose 3 $\mathrm{mg}$ ). Children who had received midazolam preinduction, were not given intraoperative midazolam. Anaesthesia was maintained by inhalation with $70 \%$ $\mathrm{N}_{2} \mathrm{O}$ and $0.75-2.0 \%$ halothane in $\mathrm{O}_{2}$. Neuromuscular blockade was maintained with mivacurium as required. Patients received in a randomized, single-blind fashion either $1.5 \mathrm{mg} \cdot \mathrm{kg}^{-1}$ codeine im in the right thigh or 1 $\mathrm{mg} \cdot \mathrm{kg}^{-1}$ ketorolac iv before the commencement of surgery. Randomization followed a computer generated random number table. A bandaid was placed on the right thigh of all subjects. The anaesthetist recorded on the anaesthetic chart that the child had received "codeine or ketorolac." Intraoperative iv fluid administration was standardized.

Upon completion of surgery, any residual neuromuscular block was reversed with $20 \mu \mathrm{g} \cdot \mathrm{kg}^{-1}$ atropine and 1 $\mathrm{mg} \cdot \mathrm{kg}^{-1}$ edrophonium. The endotracheal tube was removed after spontaneous ventilation had returned and before the return of upper airway reflexes. Intraoperative blood loss was measured using a Baxter MediVac ${ }^{\circledR}$ Universal Critical Measurement Unit. Postoperative orders were standardized. Pain was treated with morphine, $50 \mu \mathrm{g} \cdot \mathrm{kg}^{-1} \mathrm{iv}$, in the postanaesthetic recovery room (PARR), while pain after discharge from the PARR was treated initially with acetaminophen elixir, $15 \mathrm{mg} \cdot \mathrm{kg}^{-1}$, po and then with codeine $1 \mathrm{mg} \cdot \mathrm{kg}^{-1}$, im or po, if the acetaminophen was inadequate. Patients received dimenhydrinate $1 \mathrm{mg} \cdot \mathrm{kg}^{-1}$ iv slowly, if they vomited twice. Vomiting in hospital was recorded by the nursing staff. After discharge from hospital, the parents recorded all incidences of vomiting for $24 \mathrm{hr}$ after anaesthesia in a diary which was returned by mail to the research assistant (RA). When the parents were reminded $24 \mathrm{hr}$ after anaesthesia to send their diary, they were asked if their child had had any problems with vomiting, and if so, how many times did their child vomit.

Age and weight were compared by one-way ANOVA. The incidence of postoperative vomiting was compared by Chi-Square analysis. Unusual events, such as excessive bleeding, were compared by Chi-Square analysis and Exact Tests, whichever was most appropriate. An acceptable alpha error was set at 0.05 . Data are presented as mean $\pm \mathrm{SD}$.

The initial projected sample size for this study was 120 patients per group. Sample size was determined by assuming that the ketorolac-treatment would reduce the incidence of vomiting by $15 \%$. The alpha error was set 
at 0.05 (one-sided) and Type II error was at 0.20 . At the request of the Ethics Committee, interim data analysis was to be performed after 60 and 120 patients had entered the study. This analysis was reviewed by an external, non-study investigator, who was unaware of the treatment group, to determine if the there was increased bleeding in either of the study groups.

\section{Results}

Sixty-four subjects entered this study, 35 of whom received ketorolac; 29 received codeine. Demographic data were similar. The patients' ages and weights were $7.1 \pm 3.1$ and $6.8 \pm 2.7 \mathrm{yr}$, and $28 \pm 16$ and $25 \pm 11 \mathrm{~kg}$ in the codeine and ketorolac groups, respectively. Two patients in the codeine-group and three subjects in the ketorolac-group received oral benzodiazepine premedication. Induction by inhalation was used for 22 subjects in the codeine-group and 21 subjects in the ketorolacgroup. Mivacurium was administered to 21 children in the codeine-group and to 22 subjects in the ketorolacgroup.

Vomiting during the postoperative period was similar between the groups with an incidence of $31 \%$ in the codeine-group and $40 \%$ in the ketorolac-group. Two patients in each group vomited three or more times with one patient in the codeine group requiring admission to hospital because of vomiting.

Ketorolac treatment increased intraoperative and postoperative blood loss compared with codeine. Intraoperative blood loss for all patients ranged from $0-7.4 \mathrm{ml} \cdot \mathrm{kg}^{-1}$. The respective intraoperative blood losses were $1.3 \pm 0.8 \mathrm{ml} \cdot \mathrm{kg}^{-1}$ and $2.2 \pm 1.9 \mathrm{ml} \cdot \mathrm{kg}^{-1}$ (mean $\pm \mathrm{SD}$ ) for the codeine and ketorolac-treated patients, $P<$ 0.05 , ANOVA. Two ketorolac-treated patients required surgical exploration for bleeding. No major surgical bleeding was found during the reoperation. There was an increase in admission rate due to bleeding after ketorolac; five ketorolac-treated patients required admission to hospital because of bleeding, $P<0.05$, Fisher Exact Test. One of these patients required ICU for monitoring. Due to the excessive blood loss in the ketorolac group, the study was terminated for ethical reasons on the advice of the external advisor.

\section{Discussion}

We were unable to demonstrate that intraoperative ketorolac produced a lower incidence of postoperative vomiting than did codeine. Although the current investigation was discontinued prematurely, for ethical reasons, and thus has reduced power, the trend did not support our hypothesis that replacing an opioid with a NSAID would decrease postoperative vomiting. Nor did our observations support Watcha et al.' $\mathrm{s}^{3}$ results that the use of ketorolac was associated with a lower incidence of vomiting. The observed incidence of vomiting was similar to that reported previously. ${ }^{12-14}$

Excessive intraoperative and postoperative bleeding was a major problem. We observed a $14 \%$ incidence of excessive bleeding in the ketorolac group, which is greater than the expected rate of less than $3 \%{ }^{15}$ The unexpected bleeding appeared 10 be an individual response; that is, if we excluded the patients with marked bleeding from analysis, the bleeding was almost identical in groups. When we began our study, there were no reports of ketorolac being associated with important perioperative bleeding. At the time that the study was terminated, there were two reports of excessive perioperative bleeding after intraoperative ketorolac. ${ }^{16.17}$ Unlike the study of Rusy et al. ${ }^{16}$ but similar to that of Fitz-James et al. ${ }^{17}$ the bleeding we observed was associated with morbidity and was well beyond the increased "nuisance" bleeding noted by Rusy et al. during tonsillectomy.

In conclusion, the preoperative use of ketorolac increased perioperative bleeding among children undergoing tonsillectomy without any observed beneficial effects.

\section{Acknowledgements}

We thank our colleagues in Otolaryngology and Nursing for their cooperation and advice during this study. We would like to thank Phillipe Bernard, MD, PhD, FRCSC, for reviewing the data on an interim basis. We also wish to thank Ms. Marilyn Birnie, Ms. Lydia Komocar and Ms. Colline Blanchard for their vital help in conducting this investigation.

\section{References}

I Weinstein MS, Nicolson SC, Schreiner MS. A single dose of morphine sulfate increases the incidence of vomiting after outpatient inguinal surgery in children. Anesthesiology 1994; 81: 572-7.

2 Mitchell RWD, Smith $G$. The control of acute postopcrative pain. Br J Anaesth 1989; 63: 147-58.

3 Watcha $M F$, Jones $M B$, Lagueruela RG, Schweiger $C$, White $P F$. Comparison of ketorolac and morphinc as adjuvants during pediatric surgery. Ancsthesiology 1992; 76: 368-72.

4 Burns JW, Aitken HA, Bullingham RES, McArdle CS, Kenny GNC. Double-blind comparison of the morphine sparing effect of continuous and intermittent I.M. administration of ketorolac. Br J Anaesth 1991; 67: 235-8.

5 Dordoni PL, Della Ventura M, Stefanelli A, et al. Effect of ketorolac, ketoprofen and nefopam on platelet function. Anacsthesia 1994; 49: 1046-9.

6 Rorarius MGF, Baer GA, Siirtola M, Lahti T, Laippala P. 
Effect of intravenous diclofenac or indomethacin on the emergence from anaesthesia for tonsillectomy. Acta Anaesthesiol Scand 1993; 37: 616-21.

7 Reinhart DJ, Latson TW, Whitten CW, Klein KW, Allison $P M$, Patel $M$. Influence of ketorolac tromethamine on clot elastic strength in humans as assessed by thromboelastography. J Clin Anesth 1993; 5: 216-20.

8 Bean $J D$, Hunt $R$. Analgesic efficacy of ketorolac in postoperative pediatric patients. Anesth Analg 1992; 74: S20.

9 Desparmet JF, MacArthur C, MacArthur A, Grillas $B$. Pain and vomiting after tonsillectomy in children: comparison of intra-operative ketorolac and fentanyl.

Anesthesiology 1993;'79: Ȧl194.

10 Koenig HM, Cunningham FE, Andrews $C$, Zsigmond EK, Baughman VL. The effect of ketorolac vs placebo on thromboclastogram in patients undergoing surgery. Anesth Analg 1994; 78: S210.

11 Houck CS, Wilder RT, McDermott J, Berde CB. Intravenous ketorolac in children following surgery: safety and cost savings with a unit dosing system. Anesthesiology 1993; 79: Al139.

I2 Bean JD, Hunt R, Custer MD. Effects of ketorolac on postoperative analgesia and bleeding time:in children. Anesthesiology 1993; 79: A1190.

13 Splinter WM, MacNeill HB, Menard EA, Rhine EJ, Roberts DJ, Gould $M H$. Midazolam reduces vomiting after tonsillectomy in children. Can J Anaesth 1995; 42: 20I-3.

14 Splinter WM, Baxter MRN, Gould HM, et al. Oral ondansetron decreases vomiting after tonsillectomy in children. Can J Anaesth 1995; 42: 277-80.

15 Handler SD, Miller L, Richmond KH, Baranak CC. Posttonsillectomy hemorrhage: incidence, prevention and management. Laryngoscope 1986; 96: 1243-7.

16 Rusy LM, Houck CS, Sullivan $L$, et al. A double-blind evaluation of ketorolac tromethamine versus acetaminophen in pediatric tonsillectomy: analgesia and bleeding. Anesth Analg 1995; 80: 226-9.

17 Fitz-James I, Ho J, Pang LM, Siègfried R, Mannino SF, Sun $L S$. Effect of ketorolac on peri-operative bleeding \& analgesia in pediatric tonsillectomy \& adenoidectomy patients. Anesth Analg 1995; 80: S127. 